\title{
Sistem Informasi Pelayanan Pasien Puskesmas Ulunambo Di Kecamtan Menui Kepulauan Sulawesi Tengah
}

\author{
Ilin Sukma ${ }^{1}$, Muharman ${ }^{2}$, Henny $^{3}$ \\ ${ }^{1}$ fasliilinsukma@gmail.com, ${ }^{2}$ muhardlates01@gmail.com, ${ }^{3}$ henny1089@gmail.com \\ ${ }^{1,2,3}$ STMIK Catur Sakti Kendari
}

\begin{abstract}
Abstrak
Sistem informasi pelayanan pasien dalam sebuah puskesmas sangatlah penting. pendataan data pasien, data rekam medis dan pencarian data secara cepat dan akurat menjadi prioritas utama dalam sebuah puskesmas untuk membangun dan mempermudah pengolahan dan pencarian data yang lebih baik. Untuk menciptakan pendataan pasien, pengarsipan catatan medis diperlukan pengelolaan yang baik pula. oleh karena itu sangat tepat suatu Puskesmas juga memiliki layanan sistem informasi. Dalam pembuatan Sistem Informasi Pelayanan Pasien Puskesmas ini menggunakan metode Waterfall. Dari hasil penelitian yang dilakukan dapat di tarik kesimpulan bahwa Sistem Informasi Pelayanan Pasien Puskesmas Ulunambo Dikecamatan Menui Kepulauan Sulawesi Tengah telah berhasil dibuat dengan menggunakan bahasa pemoraman PHP serta DBMS MYSQL. Dengan sistem ini dapat mengelolah data pasien, rekam medis, data rawat inap dan rawat jalan.
\end{abstract}

Kata kunci: Puskesmas Ulunambo, Pelayanan Puskesmas

\begin{abstract}
Patient care information systems in a health center are very important. Patient data collection, medical record data and fast and accurate data retrieval are the top priorities in a health center to build and facilitate better data processing and searching. To create patient records, medical record archiving requires good management as well. therefore it is very appropriate that a Puskesmas also have an information system service. In making this Puskesmas Patient Service Information System using the Waterfall method. From the results of the research conducted, it can be concluded that the Patient Service Information System of Ulunambo Public Health Center in Menui District, Central Sulawesi Islands has been successfully created using the PHP language standardization and MYSQL DBMS. This system can manage patient data, medical records, inpatient and outpatient data.
\end{abstract}

Keywords: Ulunambo Puskesmas, Puskesmas Services

\section{Pendahuluan}

Dari hasil penelitian dan wawancara yang saya dapatkan bahwa Puskesmas Ulunambo yang menjadi salah satu pusat pelayanan kesehatan di Kecamatan Menui Kepulauan Sulawesi Tengah.Merupakan salah satu instansi kesehatan yang sedang dikembangkan. Dengan jumlah pasien dan data yang cukup banyak diantaranya 80 pasien perbulannya menyebabkan masalah dalam mendapatkan informasi tentang pasiennya. Dalam pengolahan atau pencarian rekam medis pasien dan data pasien rawat inap. Selain masalah pendataan pasien dan pengarsipan catatan medis merupakan suatu hal penting yang perlu diperhatikan. Apalagi di Puskesmas tersebut pendataan pasien dari mulai pendaftaran pasien dan pengarsipan catatan medis pasien masih dilakukan secara manual, artinya semuanya masih 
Jurnal Sistem Informasi dan Sistem Komputer, Vol. 5, No. 2, Oktober 2020 pISSN: 2581-1614 eISSN: 2715-906X

ditulis pada tumpukan-tumpukan kertas dan di simpan pada rak-rak penyimpanan. Sehingga ketika pihak puskesmas membutuhkan data rekam medis pasien, perlu waktu yang cukup lama untuk mencari dimana data tersebut disimpan.

Untuk menciptakan pendataan pasien, pengarsipan catatan medis diperlukan pengelolaan yang baik pula dari bagian yang menangani hal tersebut. oleh karena itu sangat tepat suatu Puskesmas juga memiliki layanan sistem informasi. Untuk membantu pengolahan data pasien, data rekam medis, data rawat inap.Dengan kemudahan dan efisiensi tersebut, diharapkan informasi yang ada dapat digunakan scara optimal, diolah sedemikian rupa, sehingga akan sangat membantu dalam menentukan tindakan- tindakan medis yang harus dilakukan.Sebagai langkah awal pengembangan sistem informasi Puskesmas Ulunambo Kecamatan Menui Kepulauan di butuhkanlah sebuah program sistem informasi puskesmas.

Maka berdasarkan data dan uraian di atas maka penulis tertarik untuk mengambil judul "Sistem Informasi Pelayanan Pasien Puskesmas Ulunambo Di Kecamatan Menui Kepulauan Sulawesi Tengah".

Tujuan dari penelitian ini adalah untuk membuat sistem informasi pelayanan dan pengolahan data pasien yang dapat memberikan solusi untuk menangani permasalahan Puskesmas Ulunambo Kecamatan Menui Kepulauan Sulawesi Tengah. Adapun manfaat dari penelitian ini adalah sebagai berikut :

1. Menciptakan sebuah sistem yang dapat mempercepat proses pelayanan dan pengolahan data pasien di Puskesmas Ulunambo.

2. Membantu kinerja para staf atau admin dalam pencarian data pasien dan rekam medis di Puskesmas Ulunambo.

3. Mengembangkan dan memajukan Puskesmas Ulunambo melalui Teknologi Informasi

Adapun batasan-batasan masalah yang akan dibahas dalam perancangan sistem informasi pelayanan pasien puskesmas ulunambo yaitu:

1. Sistem informasi yang dibuat hanya berfokus pada pelayanan dan pengolahan data pasien, data rawat inap, data rekam medis, data dokter dan Administrasi di Puskesmas Ulunambo.

2. Sistem informasi yang dibangun tidak meliputi Apotik.

\section{Landasan Teori}

\subsection{Sistem Informasi}

\subsubsection{Pengertian Sistem}

Menurut Robert G. Murdic dalam buku Analisis dan Desain Sistem Informasi[1] bahwa Sistem adalah sebagai seperangkat elemen-elemen yang terintegrasi dengan maksud yang sama untuk mencapai suatu tujuan bersama.

\subsubsection{Pengertian Informasi}

Menurut McLeod dikutip oleh [2] pada buku Pengertian Sistem Informasi, Informasi adalah data yang diolah menjadi bentuk lebih berguna dan lebih berarti bagi yang menerimanya. Sedangkan Menurut [3] pada buku Analisis Sistem Informasi, Informasi adalah data yang telah diklasifikasikan atau diolah atau diinterpretasikan untuk digunakan dalam proses pengambilan keputusan.

\subsubsection{Pengertian Sistem Informasi}

Menurut [4] Sistem Informasi adalah kumpulan elemen yang saling berhubungan satu sama lain untuk membentuk suatu kesatuan untuk mengintegrasi data, memproses dan menyimpan serta mendistribusikan informasi tersebut.

Menurut [5] Sistem informasi adalah suatu kombinasi terartur apapun dari people (orang), hardware (perangkat keras), software (piranti lunak), computer networks and data communications (jaringan komunikasi), dan database (basis data) yang mengumpulkan, mengubah dan menyebarkan informasi di dalam suatu bentuk organisasi. 


\subsection{Definisi Puskesmas}

Puskesmas (Pusat Kesehatan Masyarakat) adalah suatu organisasi kesehatan fungsional yang merupakan pusat pengembangan kesehatan masyarakat yang juga membina peran serta masyarakat di samping memberikan pelayanan secara menyeluruh dan terpadu kepada masyarakat di wilayah kerjanya dalam bentuk kegiatan pokok. Menurut [6] puskesmas merupakan unit pelaksana teknis dinas kesehatan kabupaten/kota yang bertanggung jawab menyelenggarakan pembangunan kesehatan di wilayah kerja.

Pukesmas adalah Unit Pelaksana Teknis (UPT) dari Dinas Kesehatan Kabupaten atau kota yang bertanggung jawab menyelenggerakan pembangunan kesehatan disuatu wilayah kerja.

\subsection{Model Waterfall}

Metode air terjun atau yang sering disebut metode waterfall sering dinamakan siklus hidup klasik (classic life cycle), dimana hal ini menggambarkan pendekatan yang sistematis dan juga berurutan pada pengembangan perangkat lunak, dimulai dengan spesifikasi kebutuhan pengguna lalu berlanjut melalui tahapan-tahapan perencanaan (planning), permodelan (modeling), konstruksi (construction), serta penyerahan sistem ke para pelanggan/pengguna (deployment), yang diakhiri dengan dukungan pada perangkat lunak lengkap yang dihasilkan[7].

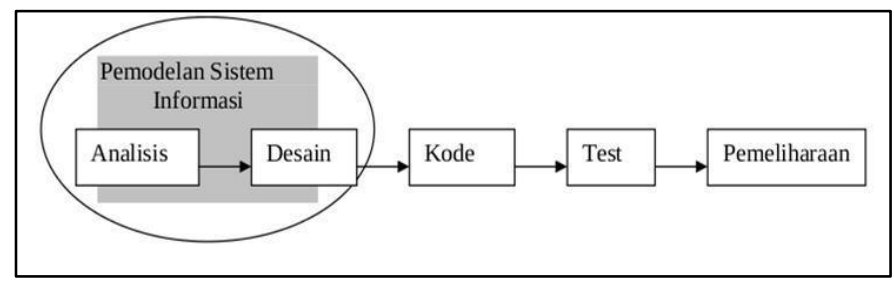

Gambar 1. Model Waterfall

Keterangan Menurut gambar diatas alur dari model waterfall sebagai berikut:

1. Tahapan Analisis

Analisis digunakan oleh sistem untuk membangun keputusan.Apabila sistem saat ini mempunyai masalah atau sudah tidak berfungsi secara baik ,dan hasil analisisnya digunakan sebagai dasar untuk memperbaiki sistem.

2. Perancangan / desain

Tahapan perancangan memiliki tujuan untuk mendesain sistem batu yang dapat menyelesaikan masalah-masalah yang dihadapi perusahaan yang diperoleh dari pemilihan alternatife sistem yang terbaik.

3. Pengkodean

Pada tahap pengkodean dilakukan proses penerapan atau implementasi dari rancangan-rancangan yang telah dibuat berupa kedalam barisan kode program (coding) yang dapat dimengerti oleh komputer.

4. Pengujian

Setelah melakukan proses tahapan pengkodean, dilakukan pengujian terhadap sistem yang telah dibangun dengan tujuan untuk melihat semua kesalahan dan kekurangan yang ada pada sistem yang telah dibangun.

5. Pendukung (support) atau pemeliharaan (maintenance)

Tahapan pendukung atau pemeliharaan merupakan tahap akhir setelah sistem di implementasikan dan dapat berjalan dengan baik, tetapi pada tahap ini, penulis tidak akan membahas proses pemeliharaan pada penulisan penelitian ini. 
Jurnal Sistem Informasi dan Sistem Komputer, Vol. 5, No. 2, Oktober 2020 pISSN: 2581-1614 eISSN: 2715-906X

\subsection{Bagan Alir (Flowchart)}

Bagan alir dokumen merupakan bagan alir yang menunjukan arus dari laporan dan formulir termasuk tembusan tembusannya. Flowmap ini menggunakan simbol-simbol yang sama dengan yang digunakan di dalam bagan alir sistem.

\subsection{Data Flow Diagram (DFD)}

Data flow diagram (DFD) adalah sebuah teknik grafis yang menggambarkan aliran informasi dan transformasi yang diaplikasikan pada saat data bergerak dari input menjadi output.

Data Flow Diagram (DFD) adalah alat pembuatan model yang memungkinkan profesional sistem untuk menggambarkan sistem sebagai suatu jaringan proses fungsional yang dihubungkan satu sama lain dengan alur data, baik secara manual maupun komputerisasi. DFD ini sering disebut juga dengan nama Bubble chart, Bubble diagram, model proses, diagram alur kerja, atau model fungsi.

\subsection{Pengertian PHP}

PHP (PHP: Hypertext Preprocessor) adalah salah satu server-side scripting yang didisain khusus untuk aplikasi web. PHP dapat disisipkan diantara bahasa HTML dan karena server-side scripting, maka skrip PHP akan dieksekusi di server sehingga yang dikirimkan ke browser adalah "hasil jadi" dalam bentuk HTML, dan kode PHP tidak akan terlihat.

\subsection{XАMPP}

XAMPP adalah perangkat lunak bebas, yang mendukung banyak system operasi, merupakan kompilasi dari beberapa program. Fungsinya adalahsebagai server yang berdiri sendiri (localhost), yang terdiri atas program Apache HTTP Server, MySQL database, dan penerjemah bahasa yang ditulis dengan bahasa pemrograman PHP dan Perl. Nama XAMP merupakan singkatan dari X (empat system operasi apapun), Apache, MySQL, PHP dan Perl. Program ini tersedia dalam GNU General Public License dan bebas. Bagian penting dari XAMPP yang biasa digunakan:

1. htdoc adalah folder tempat meletakkan berkas-berkas yang akan dijalankan, seperti berkas PHP, HTML dan skrip lain.

2. phpMyAdmin merupakan bagian untuk mengelola basis data MySQL yang ada dikomputer. Untuk membukanya, buka browser lalu ketikkan alamat http://localhost/phpMyAdmin, maka akan muncul halaman phpMyAdmin.

3. Control Panel yang berfungsi untuk mengelola layanan (service) XAMPP. Seperti menghentikan (stop) layanan, ataupun memulai (start).

Fungsi XAMPP adalah sebagai server yang berdiri sendiri(localhost), yang terdiri atas program Apache HTTP Server, MySQL databasedan penerjemah bahasa yang ditulis dengan bahasa pemrograman PHP.

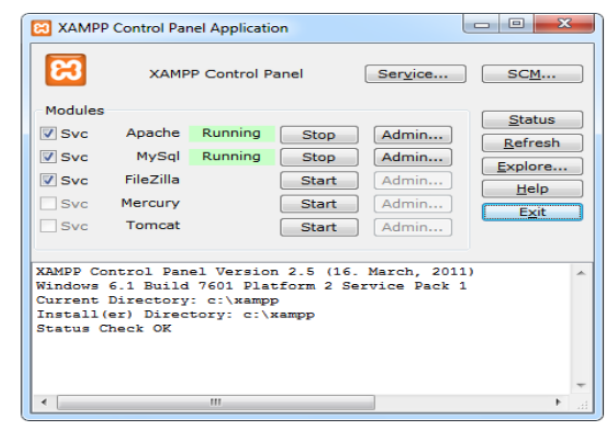

Gambar 2. XAMPP

\section{8. $\quad$ Entity Relationship Diagram (ERD)}

Pada Model Entity-Relationship, semesta data yang ada di 'dunia nyata' diterjemahkan dengan memanfaatkan sejumlah perangkat konseptual menjadi sebuah diagram data, yang umumnya disebut 
Jurnal Sistem Informasi dan Sistem Komputer, Vol. 5, No. 2, Oktober 2020 pISSN: 2581-1614 eISSN: 2715-906X

sebagai Diagram Entity- Relationship (Diagram E-R). Model Entity-Relationship dibentuk dari dua komponen yaitu entitas (entity) dan relasi (relation). Kedua komponen ini dideskripsikan lebih jauh melalui sejumlah atribut.

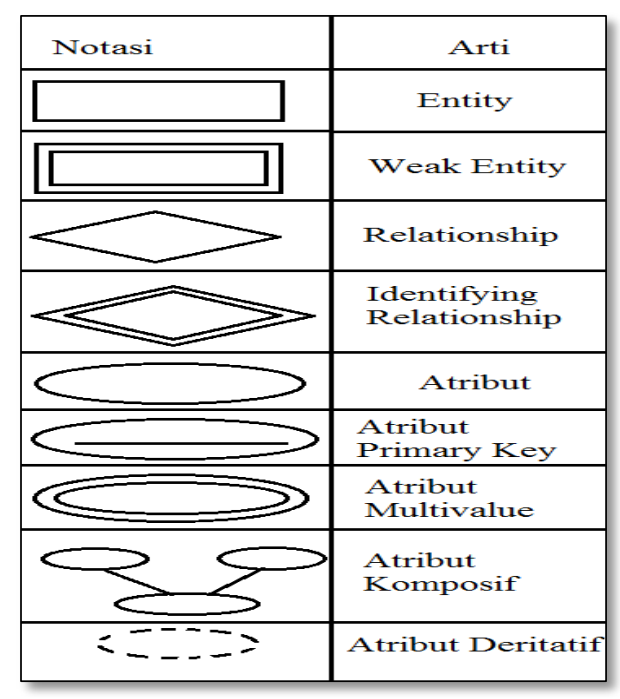

Gambar 3. ERD

\section{Metode Penelitian}

\subsection{Tempat dan Waktu Penelitian}

Penelitian ini dilakukan di Puskesmas Ulunambo, yang beralamatkan di Kecamatan Menui Kepulaun, Provinsi Sulawesi Tengah. Sedangkan waktu penelitian dilaksanakan pada tangga 20 September sampai Oktober 2018.

\subsection{Jenis dan Sumber Data}

\subsubsection{Jenis Data}

Jenis data yang digunakan dalam penelitian ini berupa data kualitatif dan data kuantitatif. Data kualitatif adalah data yang disajikan dalam bentuk kata verbal bukan dalam bentuk angka yang termasuk data kualitatif dalam penelitian ini yaitu gambaran umum .Data kualitatif diperoleh melalui berbagai macam teknik pengumpulan data misalnya wawancara, analisi dokumen, diskusi terfokus, atau observasi. Data kuantitatif adalah data yang berbentuk angka atau bilangan sesuai dengan bentuknya.

\subsubsection{Sumber Data}

Sumber data utama (primer) dari penelitian ini adalah dari lokasi penelitian yaitu pada Pukesmas Ulunambo. Sedangkan data penunjang (sekunder) berasal dari buku, internet, jurnal dan lain sebagainya. Data sekunder yang digunakan dalam penelitian ini yaitu data yang memuat pengetahuan pada tinjauan pustaka.

\subsection{Metode Pengumpulan Data}

Pada proses penyusunan proposal ini untuk mengumpulkan data yang diperlukan maka penulis menggunakan metode yaitu:
a. Metode Observasi
Metode Observasi adalah pengumpulan data yang dilakukan dengan cara mengamati dan mencatat secara sistematikan data yang diselidiki.
b. Interview jawab dengan beberapa masyarakat dan Pejabat Pelayanan Informasi, Kabupaten Muna Barat.
Untuk mendapatkan data-data secara langsung ke sumber riset, penulis langsung melakukan tanya 
c. Studi Pustaka

Dalam metode ini, pengumpulan data dilakukan dengan cara mempelajari buku-buku yang mendukung, termaksud di dalamnya literatur tentang penulisan dan mengenai hal-hal yang mendukung pembuatan program aplikasi. Juga mempelajari dari sumber data yang lain seperti dari website, jurnal, buku-buku dan media digital.

\subsection{Metodologi Pengembangan}

Metode pengembangan sistem yang dilakukan adalah dengan metode SDLC model waterfall. Model SDLC waterfall (air terjun) sering juga disebut model sekuensial linear atau alur hidup klasik. Model waterfall menyediakan pendekatan alur hidup perangkat lunak secara sekuensial atau terurut dimulai dari tahapan analisis, tahapan desain, tahapan pengkodean, tahapan pengujiandan tahapan pendukung (support) atau pemeliharaan (maintenance).

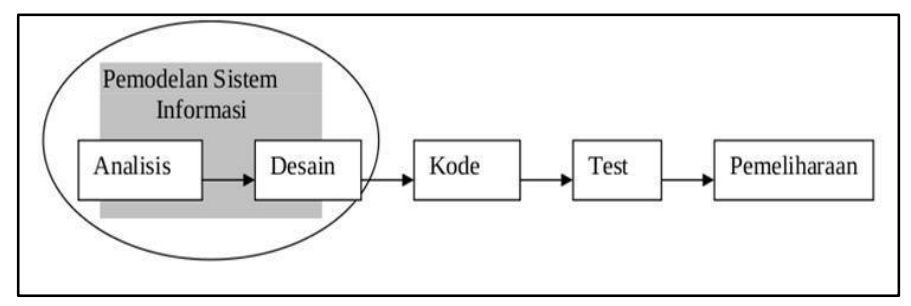

Gambar 4. Model Waterfall

\subsection{Tahapan Analisis}

1. Pada tahap analisis penulis perlu melakukan hal-hal yang berkaitan dengan kebutuhan akan datadata untuk pembuatan sistem ini. Adapun kegiatan yang dilakukan dalam analisa sistem ini meliputi identifikasi jenis data- data, prosedur pengaduan hingga tanggapan pengaduan yang dilakukan masyarakat, kebutuhan akan interface yang akan disajikan, pengolahan data serta fungsi- fungsi lain dalam sistem yang dapat mendukung dibangunnya sistem ini.

2. Desain

Pada tahap ini merupakan, desain sistem yang diusulkan dalam pembuatan Sistem Informasi layanan Aspirasi Dan Pengaduan masyarakat online Pada Kabupaten Muna ini meliputi beberapa proses diantaranya desain proses, desain basis data dan desain interface.

1. Desain proses

Pada desain proses ini, perancangan dilakukan berdasarkan permasalahan-permasalahan yang ada serta berdasarkan kebutuhan user. Seperti data flow diagram yang dirancang berdasarkan analisa untuk digunakan sebagai rancangan sistem usulan. Dalam diagram ini menggambarkan secara keseluruhan semua masukan dan keluaran yang ada dalam sistem yang akan dibangun. Diantaranya seperti proses pendaftaran user,input pengaduan yang dilakukan oleh masyarakat hingga proses menanggapi pengaduan masyarakat

2. Desain basis data

Perancangan basis data dengan menggunakan tools Entity Relationship Diagram (ERD) yang menggambarkan hubungan antar entitas-entitas pada DFD.

3. Desain antar muka (interface) sistem

Desain antar muka (interface) sistem bertujuan untuk menemukan bentuk yang baik dari tampilan aplikasi, sehingga dapat memudahkan user dalam penggunaan aplikasi.

3. Pengkodean

Pada tahap pengkodean dilakukan proses penerapan atau implementasi dari rancangan-rancangan yang telah dibuat berupa kedalam barisan kode program (coding) yang dapat dimengerti oleh komputer. 
Jurnal Sistem Informasi dan Sistem Komputer, Vol. 5, No. 2, Oktober 2020

pISSN: 2581-1614 eISSN: 2715-906X

4. Pengujian

Setelah melakukan proses tahapan pengkodean, dilakukan pengujian terhadap sistem yang telah dibangun dengan tujuan untuk melihat semua kesalahan dan kekurangan yang ada pada sistem yang telah dibangun.

5. Pendukung (support) atau pemeliharaan (maintenance)

Tahapan pendukung atau pemeliharaan merupakan tahap akhir setelah sistem di implementasikan dan dapat berjalan dengan baik, tetapi pada tahap ini, penulis tidak akan membahas proses pemeliharaan pada penulisan penelitian ini.

\subsection{Analisis Sistem Yang Berjalan}

Analisa sistem yang berjalan bertujuan untuk mengetahui proses sistem yang berjalan selama ini pada Puskesmas Ulunambo. Analisa sistem berdasarkan pengamatan dan informasi yang diperoleh dapat digambarkan dalam bentuk flowchart sistem berikut.

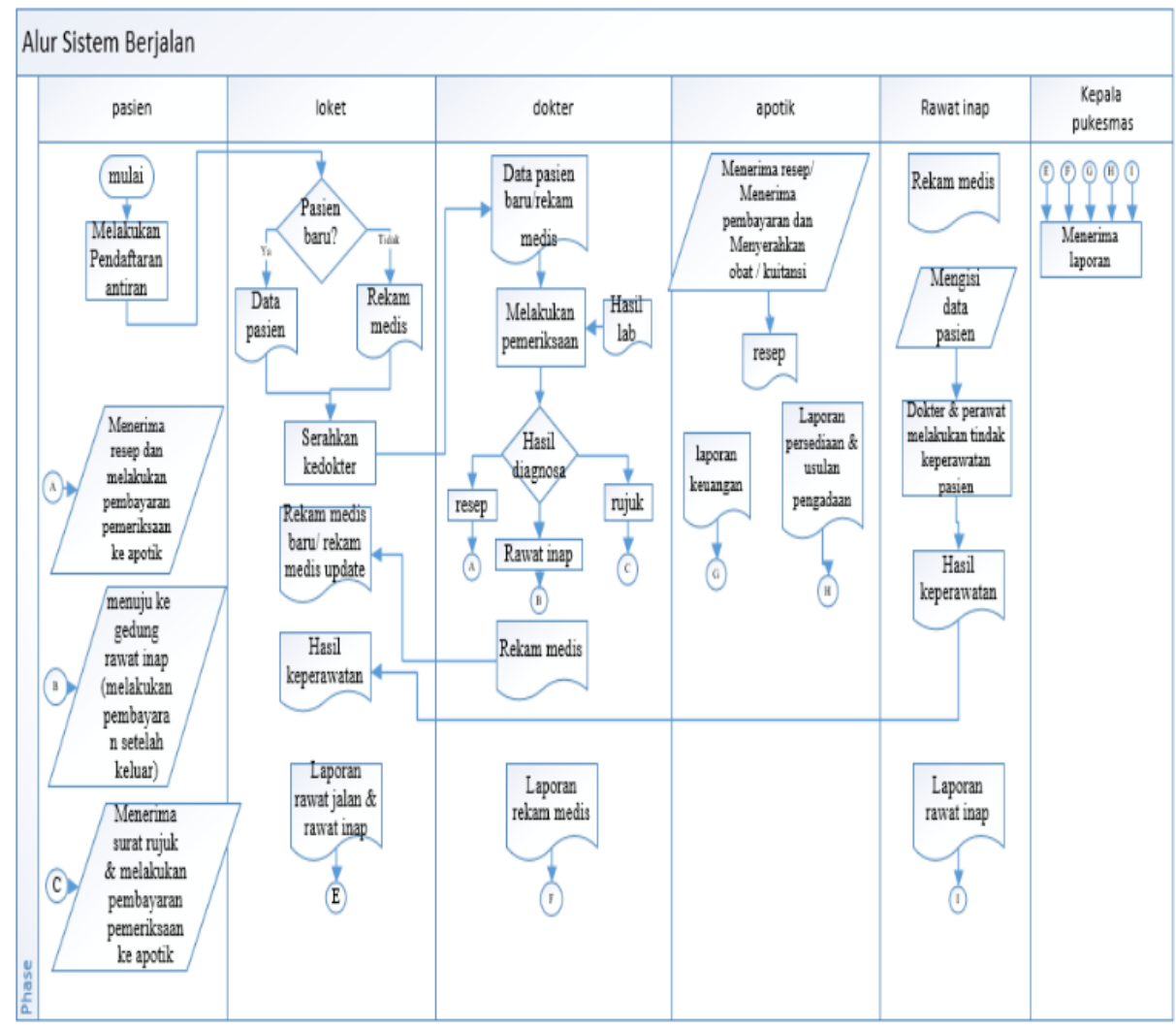

Gambar 5. Flowchart System yang Berjalan 
Jurnal Sistem Informasi dan Sistem Komputer, Vol. 5, No. 2, Oktober 2020 pISSN: 2581-1614 eISSN: 2715-906X

\subsection{Analisis Sistem Yang Diusulkan}

Analisa sistem yang Diusulkan bertujuan untuk mengetahui proses sistem yang Diusulkan pada Kabupaten Muna Barat. Analisa sistem digambarkan dalam bentukflowchart berikut:

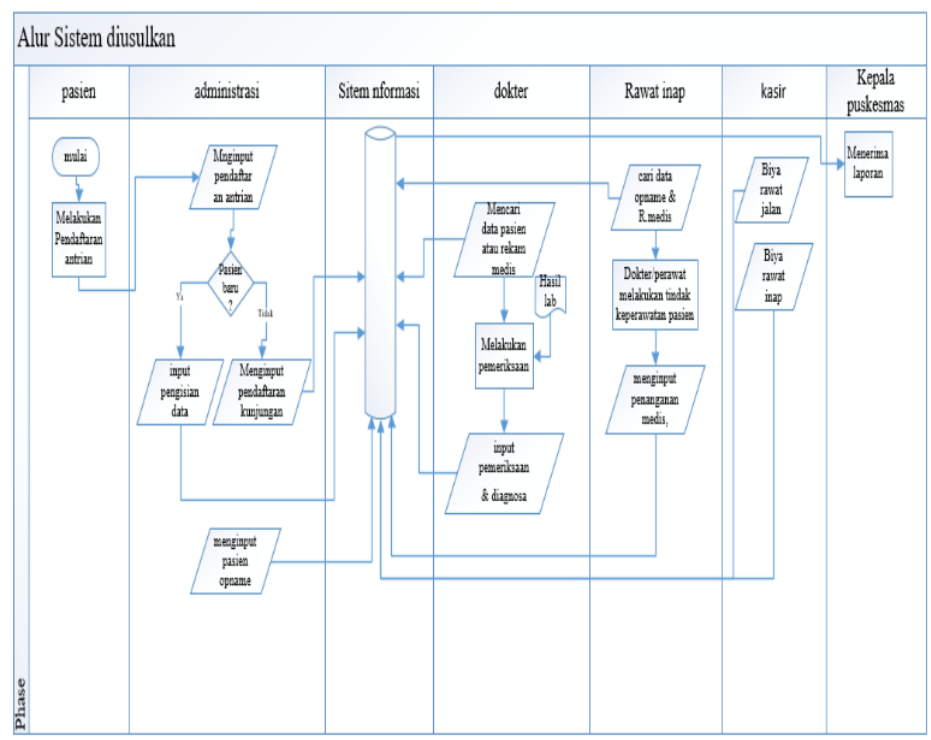

Gambar 6. Flowchart System yang Diusulkan

\subsection{Perancangan Sistem Menggunakan Data Flow Diagram (DFD)}

Diagram Konteks akan memberi gambaran umum tentang sistem informasi yang akan dibangun. Untuk mengetahui Diagram Konteks tersebut dapat dilihat melalui gambar di bawah ini :

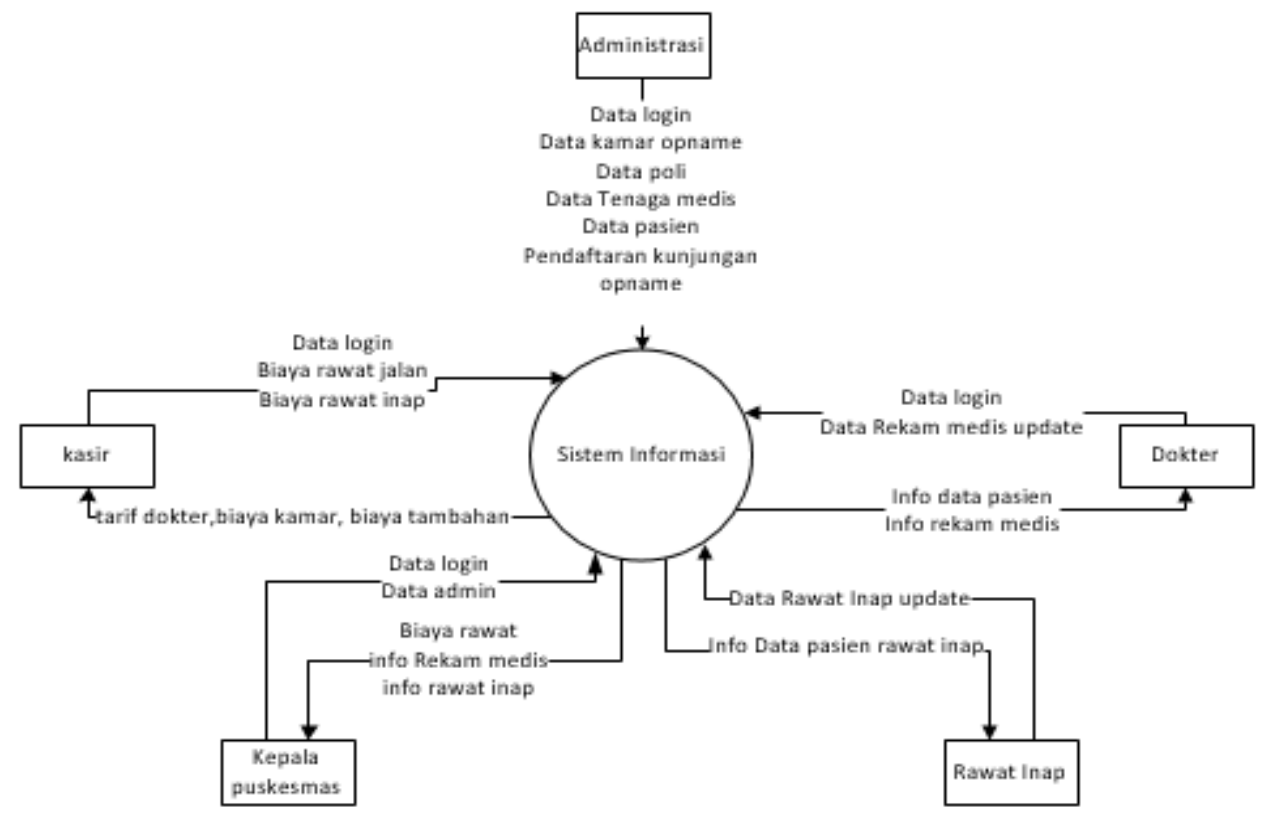

Gambar 7. Diagram Konteks 
Jurnal Sistem Informasi dan Sistem Komputer, Vol. 5, No. 2, Oktober 2020 pISSN: 2581-1614 eISSN: 2715-906X

Diagram level nol merupakan diagram alur proses yang menjelaskan secara detail proses yang terjadi antara entitas-entitas dan bagian-bagian proses yang terdapat dalam sistem. Untuk lebih jelasnya dapat di lihat pada gambar 8. dibawah ini :

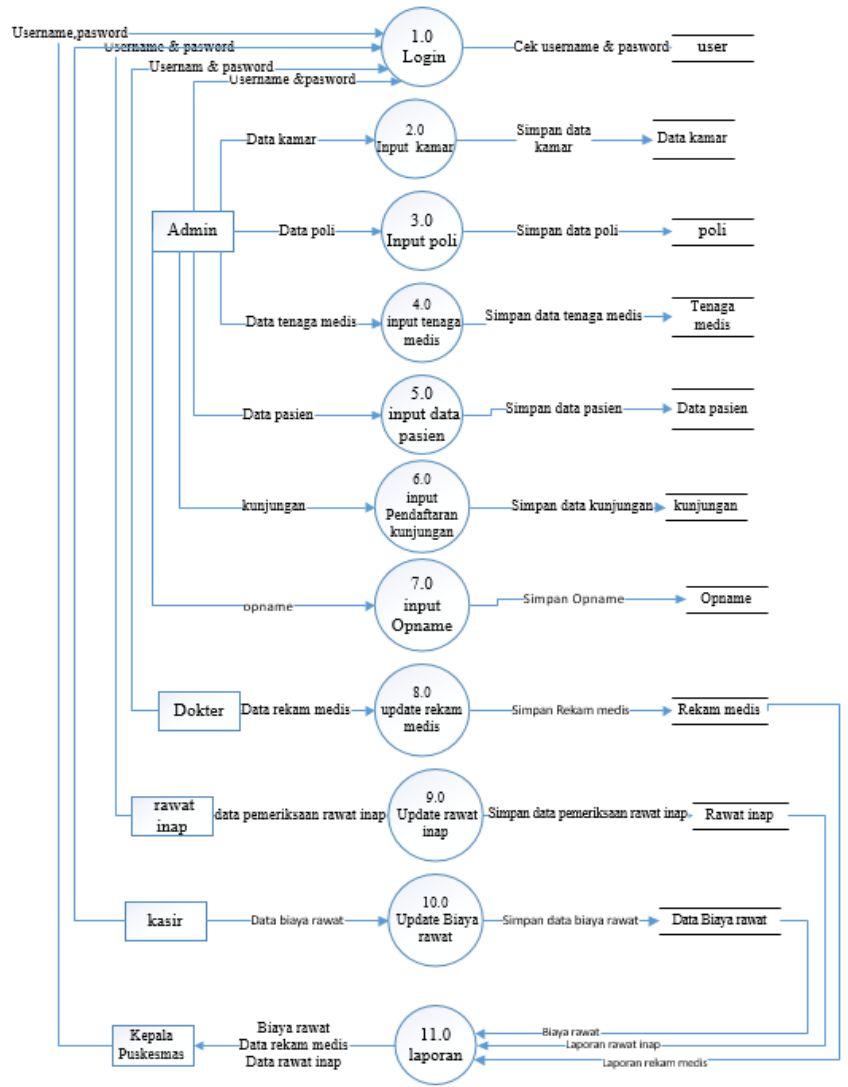

Gambar 8. Diagram Lever Nol

Entity Relationship Diagram(ERD) untuk memodelkan struktur data dan hubungan antar data, untuk menggambarkannya digunakan beberapa notasi dan simbol. Gambar di bawah ini mengambarkan bagaimana relasi antar entitas yang saling berhubungan pada proses pelayanan dan pengolahan data

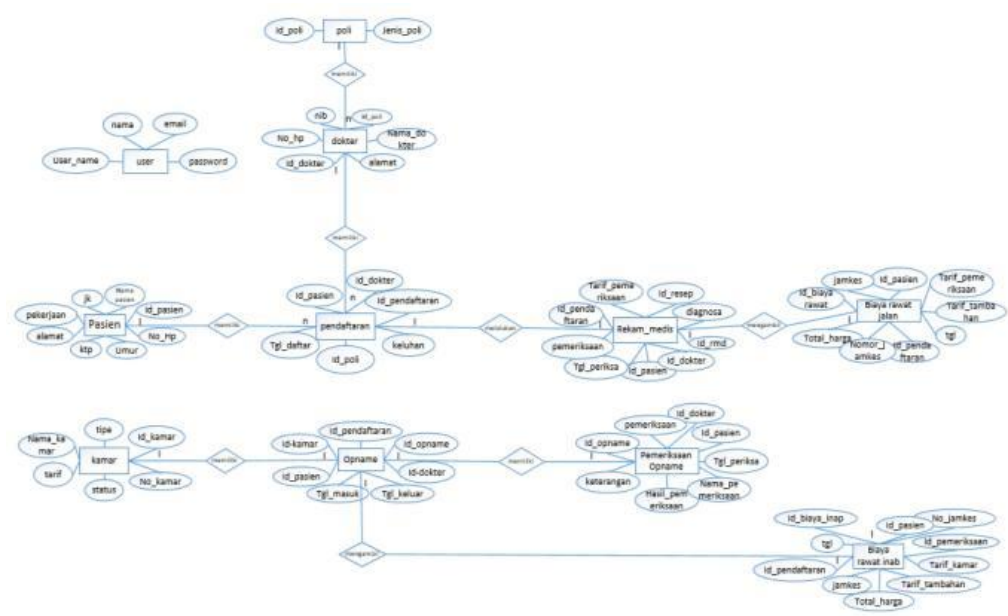

Gambar 9. Entity Relationship Diagram 
Jurnal Sistem Informasi dan Sistem Komputer, Vol. 5, No. 2, Oktober 2020

pISSN: 2581-1614 eISSN: 2715-906X

\subsection{Relasi Tabel}

Relasi tabel merupakan gambar tabel-tabel dalam database yang saling terhubung dan berkaitan. Adapun relasi tabel dalam penelitian ini dapat dilihat melalui gambar berikut ini:

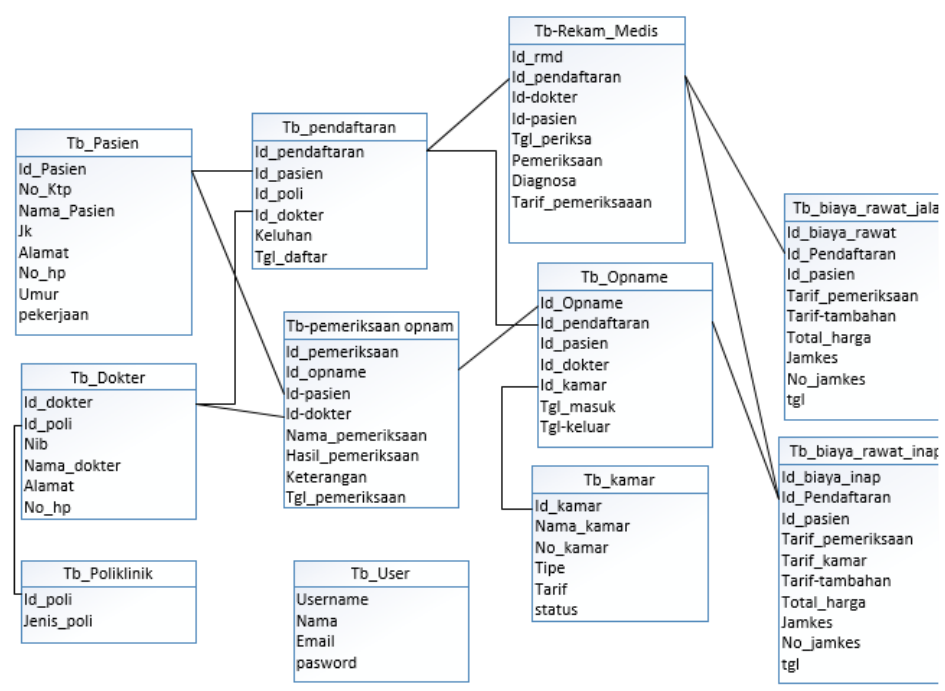

Gambar 10. Relasi Tabel

\section{Hasil Dan Pembahasan}

\subsection{Pembahasan Sistem}

Dalam tahapan bab ini menjelaskan hasil dari membuat sistem serta uji coba yang telah dilakukan dari sistem yang telah selesai dirancang dan diimplementasikan dalam bentuk aplikasi yaitu berupa website Sistem Informasi Puskesmas. Dalam perancangannya maka interface yang akan dibuat sesuai dengan fungsi utama dari sub menu, karena interface from tergantung pada informasi yang akan disampaikan.

\subsection{Profil Singkat Puskemas Ulunambo}

Puskesmas Ulunambo secara administrastif terletak di Desa Ulunambo Kecamatan Menui Kepualauan Sulawesi Tengah. Kecamatan Menui terdiri dari 24 desa, dan Puskesmas Ulunambo adalah salah satunya Puskesmas yang ada di kecamatan tersebut. Puskesmas Ulunambo berdiri sejak tahun 1973, puskesmas di renovasi dan berpindah gedung baru pada tahun 2004 dan berdiri hingga saat ini.

\subsection{Struktur Organisasi Puskesmas Ulunambo}

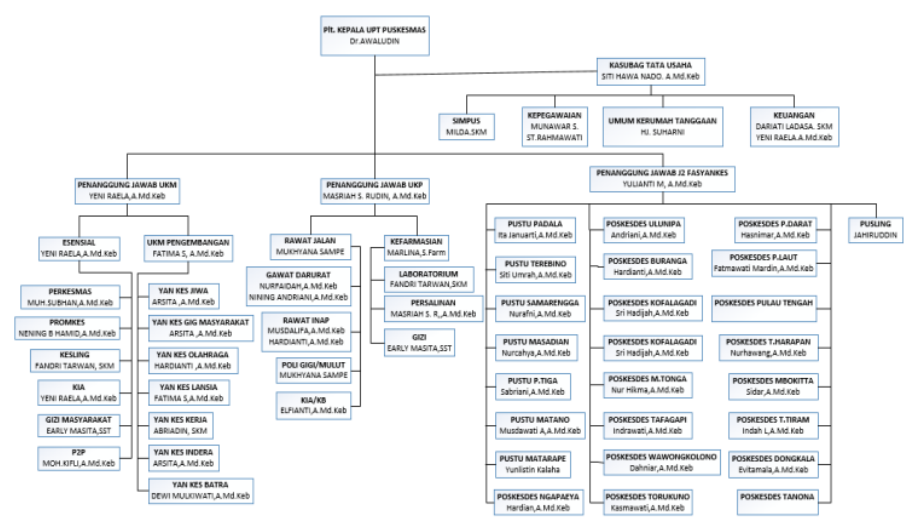

Gambar 11. Struktur Organisasi 
Jurnal Sistem Informasi dan Sistem Komputer, Vol. 5, No. 2, Oktober 2020

pISSN: 2581-1614 eISSN: 2715-906X

\subsection{Lingkungan Implementasi}

1. Perangkat Keras

Untuk mendukung sistem yang akan dibangun selain membutuhkan perangkat keras juga membutuhkan perangkat lunak, adapun perangkat keras yang digunakan dalam pengimplementasian aplikasi adalah sebagai berikut :

1. Processor AMD A8-6410 2.4 GHZ

2. RAM 8 GB

3. Harddisk $500 \mathrm{~GB}$

2. Perangkat Lunak

Perangakat lunak yang digunakan dalam pengimplementasian aplikasi adalah sebagai berikut :

1. Sistem Operasi yang digunakan windows 10

2. Web browser yang diunakan adalah Google Chrome dan Mozilla Firefox

3. Xampp versi 5.6

4. Notepad++ versi 6.8.6

Beberapa form yang digunakan dalam aplikasi Sistem Informasi Pelayanan Pasien Puskesmas Ulunambo adalah sebagai berikut:

1. Form Login

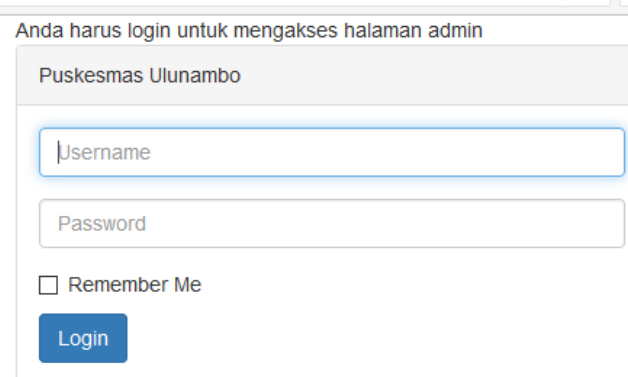

Gambar 12. Form Login

2. Halaman Beranda (Administrasi)

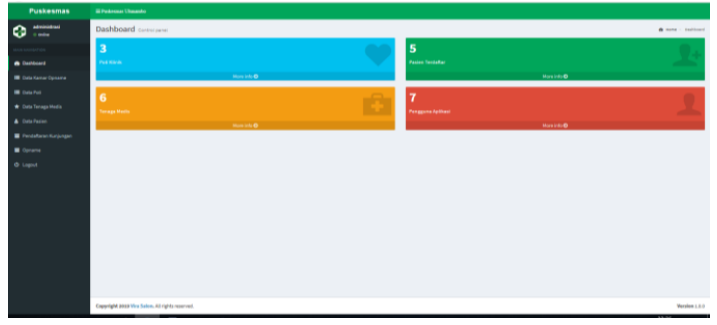

Gambar 13. Beranda

3. Halaman Data Kamar (Administrasi)

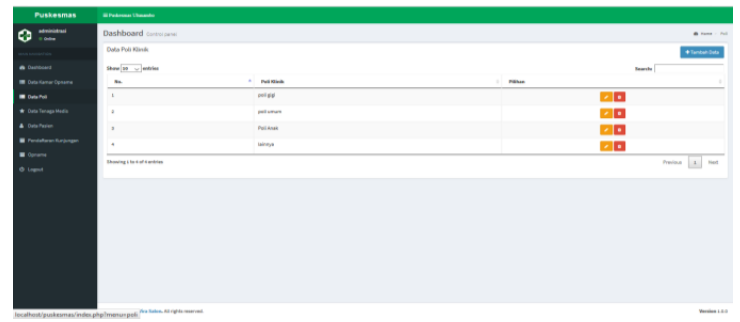

Gambar 14. Data Kamar 
Jurnal Sistem Informasi dan Sistem Komputer, Vol. 5, No. 2, Oktober 2020 pISSN: 2581-1614 eISSN: 2715-906X

4. Halaman Data Poli (Administrasi)

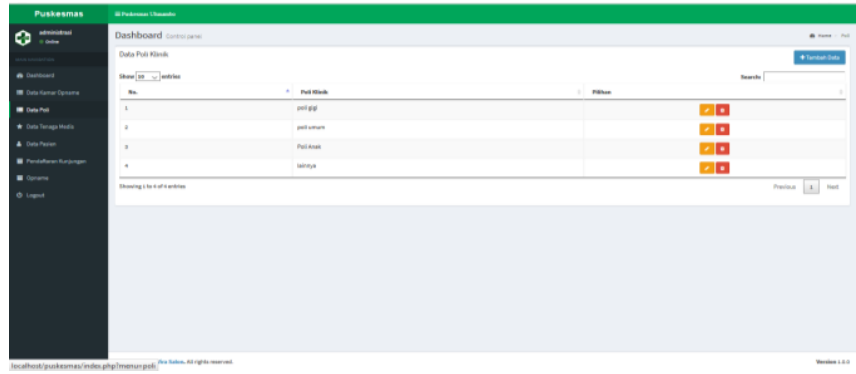

Gambar 15. Form Data Poli

5. Halaman Data Tenaga Medis (Administrasi)

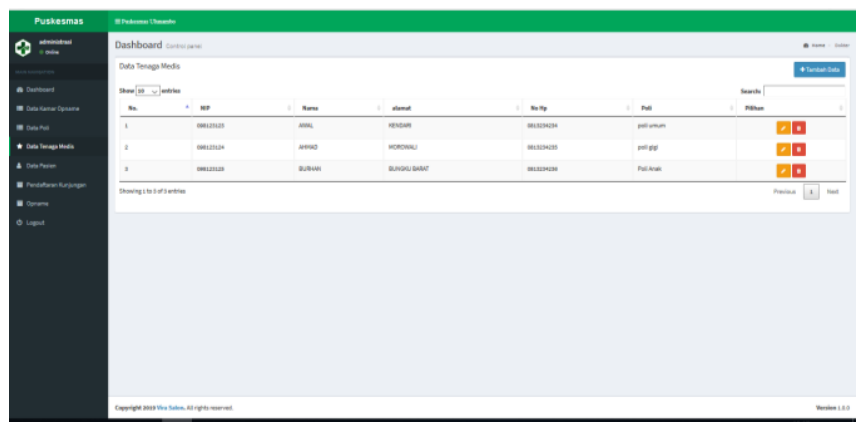

Gambar 16. Form Tenaga Medis

6. Halaman Data Pasien (Administrasi)

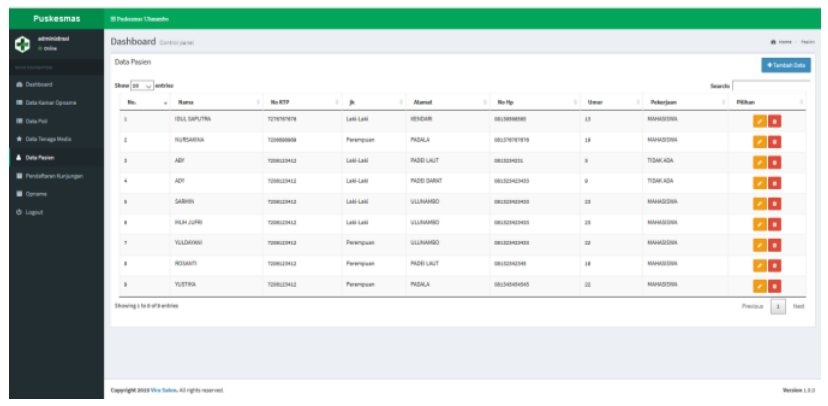

Gambar 17. Form Data Pasien

7. Halaman Pendaftaran Kunjungan (Administrasi)

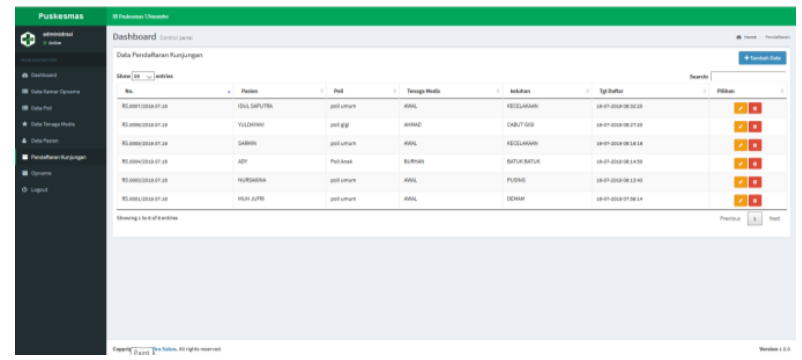

Gambar 18. Form Daftar Kunjungan 
Jurnal Sistem Informasi dan Sistem Komputer, Vol. 5, No. 2, Oktober 2020 pISSN: 2581-1614 eISSN: 2715-906X

8. Halaman Opname (Administrasi)

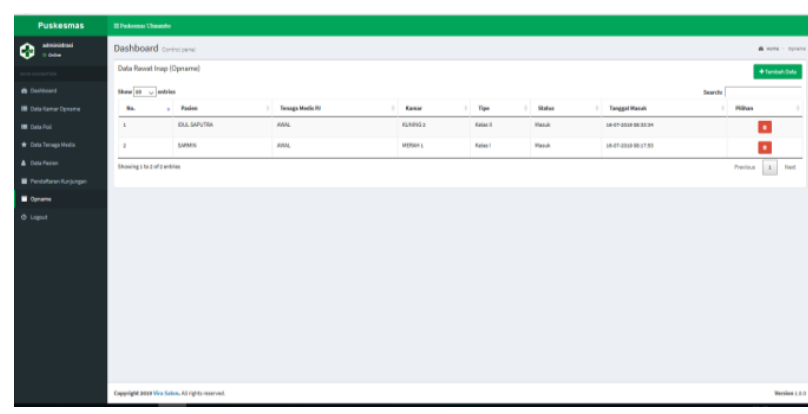

Gambar 19. Form Opname

9. Halaman Daftar Pasien (Dokter)

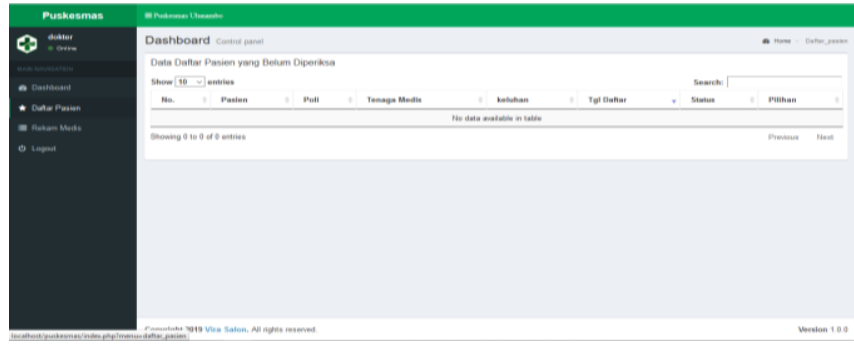

Gambar 20. Form Daftar Pasien

10. Halaman Rekan Medis (Dokter)

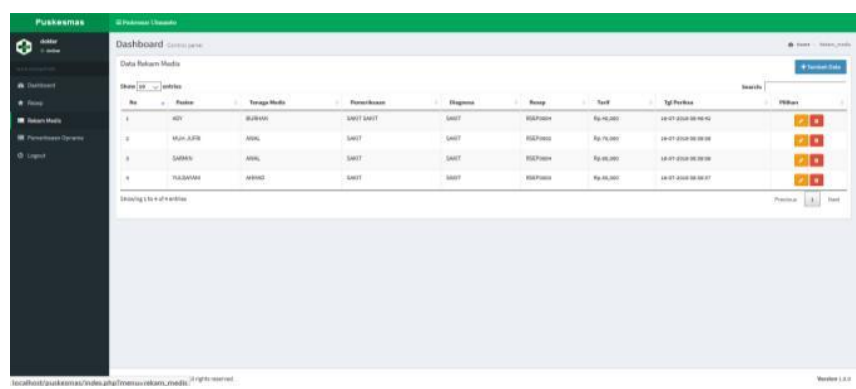

Gambar 21. Rekan Medis

11. Halaman Pemeriksaan Opname (Rawat Inap)

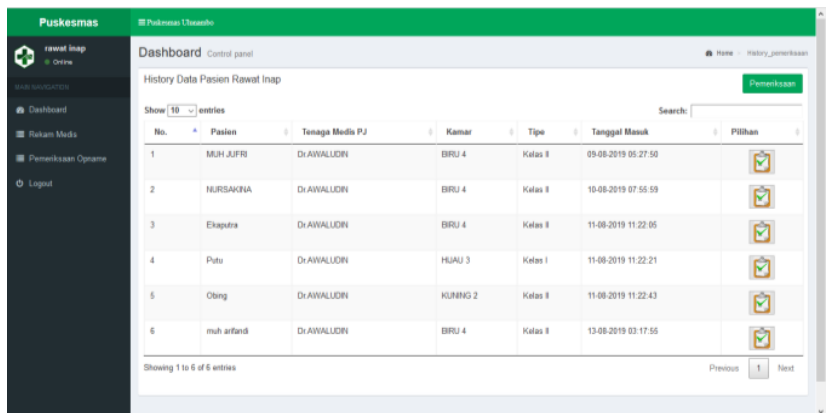

Gambar 22. Form Pemeriksaan Opname 
Jurnal Sistem Informasi dan Sistem Komputer, Vol. 5, No. 2, Oktober 2020

pISSN: 2581-1614 eISSN: 2715-906X

12. Halaman Biaya Rawat (Kasir)

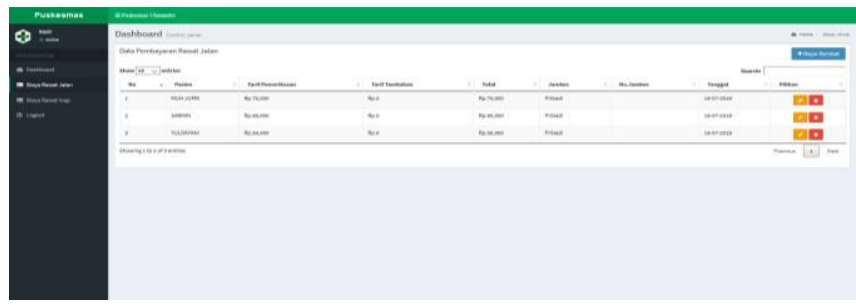

Gambar 23. Form Biaya Awal

13. Halaman Laporan (Kepala Puskesmas)

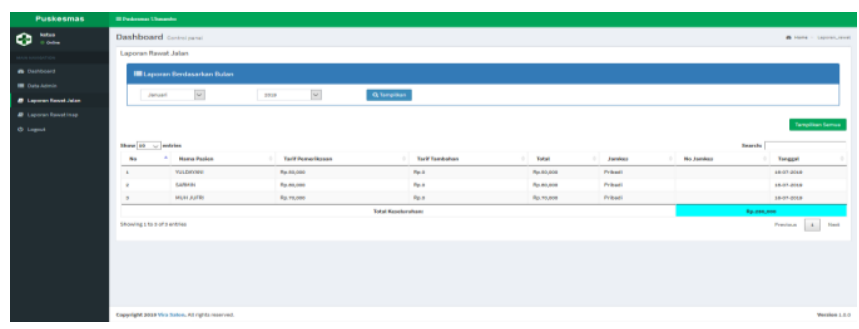

Gambar 24. Form Laporan

\section{Kesimpulan Dan Saran}

\subsection{Kesimpulan}

Dari hasil penelitian yang dilakukan dapat di tarik kesimpulan bahwa Sistem Informasi Pelayanan Pasien Puskesmas Ulunambo Dikecamatan Menui Kepulauan Sulawesi Tengah telah berhasil dibuat dengan menggunakan bahasa pemoraman PHP serta DBMS MYSQL. Dengan system ini dapat mengelolah data pasien, rekam medis, data rawat inap dan rawat jalan.

\subsection{Saran}

Diharapkan pada peneliti selanjutnya sistem ini bisa ditambahkan bagian apotik sehingga dapat mempermudah dalam pendataan pengeluaran dan pemasukan obat serta pendataan administrasi obat dalam apotik. Dan juga menambahkan bagian PUSTU (puskesmas pembantu) atau POSKESDES (pos kesehatan desa).

\section{Daftar Pustaka}

[1] B. Ladjamudin, Analisis dan Desain Sistem Informasi. 2005.

[2] Yakub, Sistem Informasi. 2012.

[3] T. Sutabri, Analisis Sistem Informasi. 2012.

[4] Budi Sutedjo Dharma Oetomo, Perencanaan dan pembangunan sistem informasi. 2002.

[5] O. Brien, Sistem Informasi Manajemen. 2005.

[6] D. RI, "Keputusan Menteri Kesehatan RI," 2004.

[7] R. S. Pressman, "Software Engineering," 2015. 